\title{
PERCEPTION RESEARCH ON DEVELOPING BRAND IDENTITY FOR SMALL CITIES
}

\section{Prof. Assoc. Dr. Serpil ÜNAL KESTANE}

Dokuz Eylül University, İzmir Vocational School, Marketing Department, serpil.kestane@deu.edu.tr

\begin{tabular}{|c|c|}
\hline Article history: & A b s t r a c t \\
\hline $\begin{array}{l}\text { Accepted } 20 \text { June } 2019 \\
\text { Available online } 20 \text { July } 2019\end{array}$ & $\begin{array}{l}\text { Global competition between countries at the macro level has turned into a competition between cities } \\
\text { at micro level. Many successful examples across the world have shown local governments and other }\end{array}$ \\
\hline Keywords: & stakeholders willing to attract more tourists or investment to their cities that more production and \\
\hline & consumption, in other words, prosperity is associated with strategic marketing of cities. Branding, \\
\hline Brand Identity, & which is part of marketing of cities willing to use their assets and resources to distinguish themselves \\
\hline Perception Research, & from others, is highly popular in both the literature and in practice. The aim of this perception study \\
\hline Köprübaşı. & is to determine the current image of small cities with few marketable resources in order to help them \\
\hline & create brand identity and an emotional bond between themselves and their target audience. This study \\
\hline & established the structural validity of a city-specific perception scale and determined how the city was \\
\hline & erceived both by its inhabitants and foreigners in terms of its concrete and abstract elements. \\
\hline
\end{tabular}

\section{Introduction}

City marketing is defined differently by management (Kotler, Kravatzis, Rufaidah, Ograjensek), geography (Paddison, Boisen), urban planning (Asworth \& Voogd, Smyth, Braun, Hospers), communication (Gelders) and engineering and design (Jiyoung Yoon) experts. For instance, Kotler's definition of city marketing is based not only on terminology but also on traditional marketing in terms of concepts and actions while business management studies perceive the city as a product and define city marketing according to product marketing theories. Despite numerous definitions, the concepts of "city marketing," "marketing place" and "city branding" are similar to each other (Asnawi, 2016).

City marketing is the process of creating and delivering value for the stakeholders of a city or a region to create economic, social and environmental sustainability (Noivana \& Rufaidah, 2012: 1275). Short et al. (2000: 318) define city marketing as reappraisal and reintroduction of the city to create and market a new image to strengthen the competitive position of local people in order to attract and retain resources.
Building a city image and communication activities to that end are an important part of city marketing strategies that allow it to stand out in the war for attention of tourists and investors. Research shows that the communication of the city image is carried out not only by promotional activities but also by other elements of marketing mix (Ashworth and Voogd 1990; Ashworth 2001). Kavaratzis (2008) argues that city marketing focuses not on the city but on its image and that marketing activities are concerned with managing the city image that distinguishes it from other cities. The objective of city marketing is, therefore, to build an original city image and city brand.

A brand occupies a distinct position according to competition and uses its functional properties and symbolic values to distinguish itself from others. Successful branding should, therefore, address the symbolic, functional and emotional needs of consumers (Hankinson \& Cowking, 1993, Rainisto, 2003). Aaker (1996) provides a framework of the city branding process consisting of strategic brand analysis, developing brand identity, brand equity, leveraging the brand and identity implementation. It is necessary to know about people's perceptions of a city to be able to develop brand identity and to create an emotional bond between the city and the target group. In other words, the identity and core values 
of a city should be taken into account and its current and future image should be identified to successfully market it. Image is a product of the mind, and a city's image is the sum of people's beliefs, ideas and impressions about that city (Ergen, 2015). Image consists of personal perceptions, and therefore, different people and/or groups have different perceptions of cities. The thoughts and impressions of inhabitants, visitors and investors of a city should be sought in order to determine its true image, and strategically designed initiatives should be implemented in accordance with city identity.

This study investigated how local people and college students from other cities perceived the district of Köprübaşı of Manisa, which one of the leading cities in agricultural and industrial production in the Aegean region of Turkey. Köprübaşı is a small Aegean district with 46 quarters inhabited by 14.045 people (2015 population data), mostly involved in agriculture. Each city has values worth marketing. Big and modern cities have many products and product groups that can be marketed. It is, however, not the case for small districts such as Köprübaş1. In 2018, the District Governorship and the Municipality carried out the "Manisa Köprübaşı District Strategic City Marketing Plan Project," from which this study is derived. ${ }^{1}$

\section{Literature Review}

There are many international and national studies on city marketing, city image and perception, the most popular of which is Aaker's work on brand personality. She developed a 42-item Brand Personality Scale consisting of 5 dimensions; sincerity, excitement, competence, sophistication and ruggedness. Afterwards, it was adapted to tourism by Hosany et al. (2006), Ekinci and Hosany (2006) and Murphy, Benkendorf and Mascordo (2007a, 2007b, 2007c). However, some researchers has raised several criticisms regarding the capacity of the adapted version of the scale to measure brand personality (Murphy, 2016). Gilboa et al. examined 39 academic studies on city image published from 2001 to 2013 and concluded that history and heritage, culture, entertainment, nightlife, infrastructure (road, communication, transportation etc.), shopping centers, environment (pollution and water), activity centers, accommodation, security, sporting facilities, parks, services, transportation, health, restaurants and green areas are criteria used to measure city image.

\footnotetext{
${ }^{1}$ This research was developed within the framework of city marketing in order to increase the effect of the "Manisa Köprübaşı District Strategic City Marketing Plan Project"
}

Rufaidah (2007) argues that city or regional governments should have city marketing strategies to achieve marketing goals, that is, economic, social and environmental sustainability. He uses three dimensions to measure city marketing, the first of which is visitability referring to the convenience of a place worth visiting and concerning with the management of domestic and foreign tourists visiting for the first time or again. To help cities achieve visibility, governments should be able to offer not only hospitality, regional destination and attraction centers but also services that make the cities attractive to visitors and tourists (Noivana and Rufaidah, 2012: 1277).

The second dimension is investability determined by labor force participation rate, investment amount, number of industrial workers, developing SMEs and migrants, and level of occupational safety. Governments should have the ability to determine and optimize the competitiveness of cities to attract investment.

The final dimension is liveability depending on education level, occupational and social activities, amount of household waste processed by the hygiene department, amount of consumption, management of permanent residents and migrants who settle in the city and availability of clean water and air. In short, according to Rufaidah, the three dimensions of city marketing are visibility, investability and livability.

Rufaidah and Noivana (2012:1277) measured the three dimensions of city marketing and showed that the concept of city marketing can be conceptualized as a multidimensional structure. They stated that competition between places or cities is related to striking changes in the distribution of economic power. Different from commercial businesses, places compete to increase attraction to potential target markets such as mobile investments, tourism, mega events and specialist human resources.

Karavatzis (2004) argues that city branding is based on the physical structure of the city and on the interaction of subjective perceptions of complex mental messages about the city and that city image communication involves three dimensions. The first of these is the concrete (physical structure and infrastructure) and abstract elements of the city (such as management structure, social structure, vision and culture behavior patterns). The second level involves the elements of marketing mix while the third one is word-of-mouth advertising.

carried out by Manisa Celal Bayar University in collaboration with Köprübaşı District Governorate, Manisa Metropolitan Municipality and Köprübaşı Municipality in 2018. 
Merriless et al. (2009) conducted research in Gold Coast, Queensland, Australia and reported that climate and natural assets followed by security, cultural events and festivals significantly improve the image of the city. They also addressed the sustainability aspect of the city and pointed out that the inhabitants attach great importance to growth and sustainability, and therefore, employment opportunities should be created in the city. They also stated that shopping, cuisine, a clean environment, and transportation and government services also affect people's perceptions of the city.

There are some studies conducted in Turkey as well. Acar et al. (2015) made conceptual and theoretical explanations of the city identity of Gaziantep. Gelibolu et al. (2014) addressed the image and brand identity of Kars and presented findings regarding its popularity and visibility. The Eastern Anatolia Development Agency (2014) carried out a study on the branding and marketing of products produced in the city of Muş and discussed the issue of city branding as well. The Izmir Development Agency (2015) conducted a study on the urban marketing strategic plan of İzmir and referred to perception studies on city image. Frrat and Kömürcüoğlu (2015) discussed the issues of personality, quality, identity, utility and communication of the city of Muğla. Focusing on the requirements of being a brand city, Özdemir and Karaca discussed the image and people's perceptions of the physical, abstract and urban image of Afyon.

The first step in developing a city brand is to determine how that city is perceived by its target audience. The aim of this study was, therefore, to determine how Köprübaşı was perceived by local people and college students who are from different cities.

\section{Material and Method}

The main objective of this study was to determine how people perceived Köprübaşı in order to achieve city marketing and to contribute to the city's branding process. The study regarded Köprübaşı as a potential city brand and investigated local people's and college students' perceptions of it. Various scales were used to develop the Köprübaşı District Perception Scale (KDPS) used to measure participants' perceptions of Köprübaş1. The KDPS consisted of four sections; (1) demographic characteristics of participants and (2) concrete, (3) abstract and (4) public image of Köprübaşı.

Özdemir and Karaca's scales were used to measure the abstract image and the public image of Köprübaşı. Özdemir and Karaca listed the variables as semantic differences in the abstract image. The same scale was used in this study, and participants were asked to mark the category that correlated with their thoughts about the district on a scale of 1 (most negative) to 5 (most positive). Their scores were averaged to calculate a perception score for each adjective (Table 1) (Özdemir and Karaca, 2009: 117).

Table 1. Abstract Image Scale

\begin{tabular}{|l|l|l|l|l|l|l|}
\hline Exhausting & 1 & 2 & 3 & 4 & 5 & Relaxing \\
\hline Boring & 1 & 2 & 3 & 4 & 5 & Exciting \\
\hline Dull & 1 & 2 & 3 & 4 & 5 & Alive \\
\hline Not Nice & 1 & 2 & 3 & 4 & 5 & Very Nice \\
\hline Unsafe & 1 & 2 & 3 & 4 & 5 & Safe \\
\hline Chaotic & 1 & 2 & 3 & 4 & 5 & Orderly \\
\hline Expensive & 1 & 2 & 3 & 4 & 5 & Cheap \\
\hline
\end{tabular}

Source: Adapted from Özdemir and Karaca, ibid. 2009, 129-130 and Gallipoli et al. ibid. 2014, p.45

The studies conducted by Y1lmaz and Yücel (2013: 66), Özdemir and Karaca (2009: 117) and Gelibolu et al. (2014: 59) were utilized to measure the public image of the district. The scale assessed 12 variables; commitment to tradition, hospitality, friendliness, helpfulness, generosity, honesty, courtesy, sociability, modernity, boredom, reliability and diligence.

The study sample consisted of college students from different cities and local people of Köprübaşı. Since college students come from all over the country, they can compare Köprübaşı with other districts and cities and evaluate it from an outside perspective. Students are, therefore, an important target group to determine how the district is perceived from outside. The local community is the second target group and their perceptions of the district will provide important data, which also provide an insider's view of the district.

The KDPS was first administered to local people. CFA was performed and construct validity was tested (referring to your work). Then it was administered to college students. Data were analyzed using the Excel, Amos and SPSS.

\section{Analysis Results and Findings}

\subsection{Exploratory and Confirmatory Factor Analysis Results}

An EFA was applied to the KDPS. Literature review showed that three different scales are used to measure the public, abstract and concrete images grouped under one factor. The same method was used in this study and each dimension was considered a separate scale (Kestane et al., 2018: 432).

Table 2 shows the factor loads, total variance coverage ratio and reliability of the items. 
Table 2. EFA Factor Loads and Reliability.

\begin{tabular}{|c|c|c|c|c|c|}
\hline Public image & $\begin{array}{l}\text { Factor } \\
\text { Loads } \\
\end{array}$ & Concrete image & $\begin{array}{l}\text { Factor } \\
\text { Loads }\end{array}$ & Abstract image & Factor Loads \\
\hline Traditionalist & 0.775 & History & 0.724 & Exhausting/Relaxing & 0.779 \\
\hline Hospitable & 0.872 & Cuisine & 0.699 & Boring/Exciting & 0.729 \\
\hline Friendly & 0.884 & Security & 0.670 & Dull/Alive & 0.756 \\
\hline Helpful & 0.878 & Hygiene & 0.712 & Nice/Not Nice & 0.865 \\
\hline Generous & 0.893 & Nature & 0.752 & Safe/Unsafe & 0.784 \\
\hline Honest & 0.893 & In-district Transportation & 0.778 & Orderly/Chaotic & 0.811 \\
\hline Kind & 0.849 & $\begin{array}{l}\text { Out-of-district } \\
\text { Transportation }\end{array}$ & 0.793 & Expensive/Cheap & 0.769 \\
\hline Social & 0.757 & Accommodation & 0.816 & \multicolumn{2}{|c|}{ Total Variance Explained $61.7 \%$} \\
\hline Modern & 0.742 & Cultural/Social/Sports & 0.803 & \multicolumn{2}{|c|}{ Reliability 0.89} \\
\hline Boring & 0.515 & Urbanization & 0.826 & & \\
\hline Reliable & 0.804 & $\begin{array}{l}\text { Eating/drinking/entertainme } \\
\text { nt }\end{array}$ & 0.840 & & \\
\hline \multirow[t]{2}{*}{ Hardworking } & 0.741 & Shopping & 0.831 & & \\
\hline & & Climate & 0.710 & & \\
\hline \multicolumn{2}{|c|}{ Total Variance Explained $65.1 \%$} & \multicolumn{2}{|c|}{ Total Variance Explained 58.9\% } & & \\
\hline \multicolumn{2}{|c|}{ Reliability 0.94} & \multicolumn{2}{|c|}{ Reliability 0.94} & & \\
\hline
\end{tabular}

Source: Kestane et al., 2018:433.

All these results showed that the concrete, abstract and public image scales had construct validity. The concrete and public image scales were highly reliable $(\alpha=0.94)$ and the abstract image scale was reliable $(\alpha=0.89)$. The AFA results showed that the KDPS was a reliable scale consisting of 3 subscales; public, concrete and abstract image.

Second level confirmatory factor analysis (SLCFA) was also performed on the scales. The KDPS consisted of three subscales and a total of 32 items (13 items for concrete image, 12 items for public image and 7 items for abstract image) (Kestane et al. 2018:435). Confirmatory factor analysis shows that concrete image (0.89) is the most important factor affecting perception, followed by public image (0.81) and abstract image (0.66).

Item $3(0.83)$ and Items 2 and $4(0.82)$ have the highest correlation with concrete image, suggesting that the more improved the entertainment and shopping opportunities and urbanization level, the better the concrete image of the district. Item 11 (cuisine) has the lowest correlation with concrete image.

Items 21 and 22 (0.91) have the highest while item 26 (boredom) has the lowest correlation with public image, suggesting that the more generous and honest the Köprübaşı people, the better the public image.

Items $16(0.85)$ and $27(0.66)$ have the highest and lowest correlation with abstract image, respectively, suggesting that the nicer the district, the better the abstract image.

The SLCFA goodness of fit values are as follows:

Table 3. The SLCFA goodness of fit values

\begin{tabular}{|l|l|l|l|l|l|l|l|l|l|}
\hline Cmin/df & NFI & RFI & IFI & CFI & RMSEA & GFI & Chi-square & df & P \\
\hline 3.487 & 0.926 & 0.917 & 0.946 & 0.946 & 0.059 & 0.887 & 1094.856 & 314 & 0.0000 \\
\hline
\end{tabular}

Table 3 shows that the KDPS has a high goodness of fit.

\subsection{Findings}

213 students of the Köprübaşı Vocational School (KVS) of Celal Bayar University participated in the study. Face-to-face interviews were conducted with them. As has been stated before, students are an important target group for this research because they come from all over the country, and therefore, are likely to provide important information on how Köprübaşı is perceived from outside.
The image of a city cannot be separated from its inhabitants for they are the most important architects of traditions and culture. This study, therefore, investigated how local people perceived Köprübaş1 as well. Questionnaire forms were distributed to 900 local people, 727 of which were found to be suitable for analysis. Findings are given below.

\subsubsection{Demographic Characteristics of Participants}

Table 4 summarizes the participants demographic characteristics. Of 213 students, $60 \%$ are women, $99.5 \%$ are 
single, $69.5 \%$ are 20 years of age or younger and $71 \%$ have an income of $2000 \mathrm{TL}$ or less. They have been living in Köprübaş1 for 1 to 5 years and come from all over the country, mostly from İzmir and Manisa and its districts, followed by Aydın, Muğla and Balıkesir. There are also some students from Van, Edirne,
Diyarbakır and Trabzon. Of 727 local people, $45 \%$ are women, $50 \%$ are married, $27 \%$ are between the ages of 21 and 30 years and $54 \%(32 \%+22 \%)$ have an income between 0 and 2000 TL.

Table 4. Demographic Characteristics of Participants

\begin{tabular}{|c|c|c|c|c|c|}
\hline \multicolumn{3}{|c|}{ Demographic Characteristics of Students } & \multicolumn{3}{|c|}{ Demographic Characteristics of Local People } \\
\hline Gender & f & $\%$ & Gender & f & $\%$ \\
\hline Woman & 128 & 60 & Woman & 325 & 45 \\
\hline Man & 85 & 40 & Man & 402 & 55 \\
\hline Total & 213 & 100 & Total & 727 & 100 \\
\hline Marital Status & f & $\%$ & Marital Status & f & $\%$ \\
\hline Single & 212 & 99.5 & Single & 368 & 51 \\
\hline Married & 1 & 0.5 & Married & 359 & 49 \\
\hline Total & 213 & 100 & Total & 727 & 100 \\
\hline Age (Years) & f & $\%$ & Age (Years) & f & $\%$ \\
\hline 20 or younger & 148 & 69.5 & 20 or younger & 166 & 23 \\
\hline $21-30$ & 62 & 29.1 & $21-30$ & 196 & 27 \\
\hline $31-40$ & 1 & 0.5 & $31-40$ & 127 & 17 \\
\hline 41 or older & 2 & 0.9 & 41 or older & 238 & 33 \\
\hline Total & 213 & 100 & Total & 727 & 100 \\
\hline Income (TL) & f & $\%$ & Income (TL) & f & $\%$ \\
\hline 2000 or less & 152 & 71 & 2000 or less & 394 & 54 \\
\hline $2001-4000$ & 8 & 4 & $2001-4000$ & 194 & 27 \\
\hline 4001 or more & 4 & 2 & 4001 or more & 51 & 7 \\
\hline Unstated & 49 & 23 & Unstated & 88 & 12 \\
\hline Total & 213 & 100 & Total & 727 & 100 \\
\hline $\begin{array}{l}\text { Life in Köprübaşı } \\
\text { (Years) }\end{array}$ & f & $\%$ & Life in Köprübaşı (Years) & f & $\%$ \\
\hline 5 or less & 170 & 80 & 5 or less & 286 & 39 \\
\hline $6-11$ & 5 & 2 & $6-11$ & 85 & 12 \\
\hline 12 or more & 38 & 18 & 12 or more & 325 & 45 \\
\hline Total & 213 & 100 & Unstated & 31 & 4 \\
\hline & & & Total & 727 & 100 \\
\hline
\end{tabular}

\subsubsection{Findings}

\section{- What Köprübaşı Brings to Mind}

All participants were asked what was the first thing that came to mind when they thought of Köprübaşı. The purpose of this question was to identify the flagship product that can be used to promote the district. Participants' responses are listed in Table 5. The first things that came to their minds were strawberries, tobacco, dam and olives. However, both students and local people first thought of strawberry.

Table 5. What Köprübaşı Brings to Mind

\begin{tabular}{|c|l|l|}
\hline $\begin{array}{l}\text { Order of } \\
\text { Precedence }\end{array}$ & Students & Local People \\
\hline 1. & Strawberries & Strawberries \\
\hline 2. & Dam & Dam \\
\hline 3. & Coffeehouses & Tobacco and olives \\
\hline 4. & Terrace Cafe & Olives \\
\hline 5. & $\begin{array}{l}\text { Olives and } \\
\text { tobacco }\end{array}$ & Fish and dam \\
\hline
\end{tabular}

\section{Recommending Köprübaşı}

To the question "Would you recommend people you know to come and visit Köprübaşı? Why or why not?" $22 \%$ of the students and $66 \%$ of the local people responded "yes" (Graph 1).
Graph 1. Recommending Köprübaş1

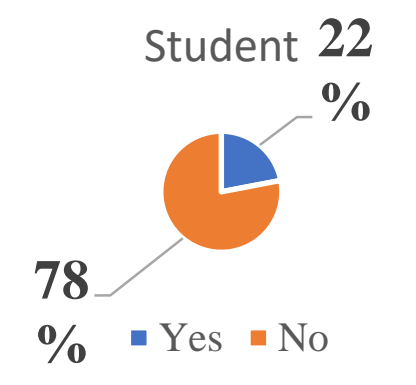

Local People

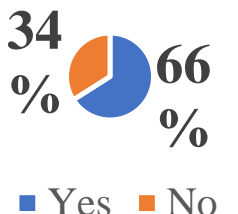

- Yes - No

The students who stated that they would not recommend people to visit Köprübaşı justified their responses as follows: There are accommodation problems in Köprübaş1; There is no such thing as 
social life; there is nowhere to spend the day; It is an undeveloped place and people cannot meet their general needs like entertainment and shopping; There is nowhere to go; It does not have a proper environment; there are no theatres; Everything is too expensive; There are no social activities; Transportation is difficult; It does not have proper roads.

The students who stated that they would recommend people to visit Köprübaşı justified their responses as follows: It is a quiet and calm place to rest; There is no traffic; It is a safe place; I recommend it for education because there is nothing to do other than studying; It is a good place for retirement.

The local people who stated that they would recommend people to visit Köprübaşı justified their responses as follows: It has a peaceful social life; It has an unspoiled nature and decent people; It is suitable for development and investment; Its agricultural sector is self-sufficient; One can live there without having to take great risks; There is no corruption; It is safe and has fresh air and lovely climate; Life is cheap there; One would not starve here; It is one of the most beautiful districts for retired people.

The local people who stated that they would not recommend people to visit Köprübaşı justified their responses as follows: It is culturally and socially weak; People go and live somewhere else; Transportation is inconvenient; There are no jobs; There are health problems; There are no activities; There are no places to go and have fun.

\section{If Köprübaşı were a Person}

Participants were asked "If Köprübaşı were a person, what kind of person would it be?" The purpose of this question was to determine the distinct characteristics of the district to use them for branding. Participants' responses are summarized in Table 5.

Table 5. What Kind of Person would Köprübaşı Be?

\begin{tabular}{|l|l|l|l|}
\hline Students & \% & Local People & \% \\
\hline Bad & 22.1 & Good & 39.8 \\
\hline Ugly & 23 & Beautiful & 22.7 \\
\hline Old & 43.7 & Old & 34.9 \\
\hline Calm & 37.1 & Calm & 44 \\
\hline Man & 16.9 & Man & 20.9 \\
\hline
\end{tabular}

Students stated that if Köprübaşı were a person, it would be a bad, calm and ugly old man while local people stated that it would be a good, calm and beautiful old man.

This result shows that branding activities should focus on changing the "bad, ugly and old" image of Köprübaşı to a "good, beautiful and young" image and reinforce the "calm man" image.

\section{Colors of Köprübaşı}

Participants were asked "What colors do you think symbolize Köprübaşı?" The purpose of this question was to determine suitable colors to be used for the promotion of the district. Graph 2 shows the participants' responses. Of the students $24.4 \%$ chose black, $31.9 \%$ turquoise and $99.5 \%$ turquoise. Of the local people, $13.20 \%$ chose red, $23.5 \%$ green and $18 \%$ turquoise.

Graph 2. Colors of Köprübaş1

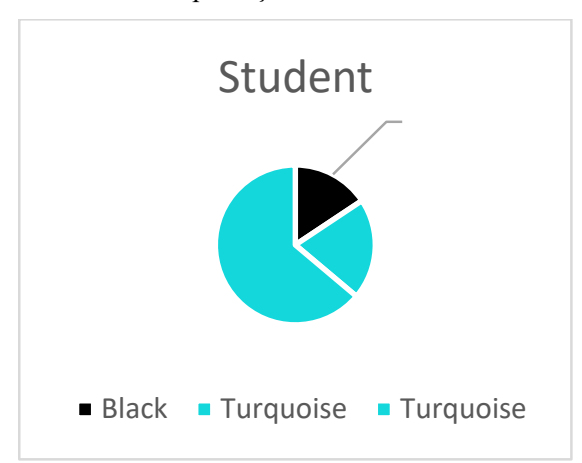

1) Black, 2) Turquoise, 3) Turquoise

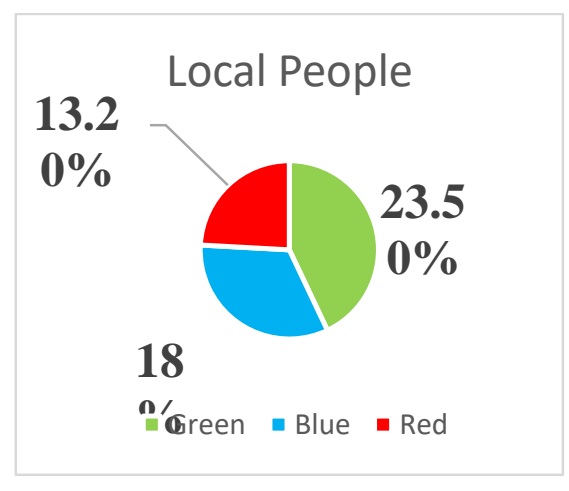

1) Green, 2) Blue, 3) Red

\section{Dream Köprübaşı}

Participants were asked "What is your dream Köprübaşı?" to determine the vision of the district. The students answered the question as: It is an orderly, vibrant and developed district with shopping malls, social and cultural activities, entertainment venues, recreation and picnic areas, advanced industry, high living standards, colorful houses, green areas and advanced health, education and transportation services.

The local people answered the question as: It is an advanced, industrialized and popular city-like district with accommodation, transportation and health services, a renovated bazaar, arts and cultural events, shopping and entertainment centers and job opportunities with shops, businesses and factories that will help prevent the migration of young people. 
Qualities That Should be Highlighted for the Development of the District

Participants were asked "What qualities of Köprübaşı should be highlighted?" The purpose of this question was to determine suitable qualities to be used for the promotion of the district. $75 \%$ of the students and $86.2 \%$ of the local people responded it as "agricultural products."

Table 6. Qualities That Should be Highlighted for the Development of the District

\begin{tabular}{|l|l|l|}
\hline Qualities & Students (\%) & Local People (\%) \\
\hline Agricultural products & 75 & 86.2 \\
\hline Industry & 3 & 3.7 \\
\hline Service & 6 & 3.9 \\
\hline Tourism attractions & 4 & 1.5 \\
\hline $\begin{array}{l}\text { Cultural artistic } \\
\text { (architecture, } \\
\text { activities etc.) }\end{array}$ & 1.5 \\
\hline
\end{tabular}

\section{People's Perceptions of Concrete Image of Köprübaşı}

Regarding the concrete image of Köprübaşı, participants were asked to score 13 variables on a scale of 1 (most negative) to 5 (most positive). Those variables were history, cuisine, security, cleanliness, nature, transportation in and out of the district, accommodation, cultural/social/sporting activities, urbanization, eating/drinking/entertainment, shopping and climate. Graphs 3 and 4 provide a summary of the students' and local people' responses, respectively.

Graph 3. Students' Perceptions of Concrete Image of Köprübaş1

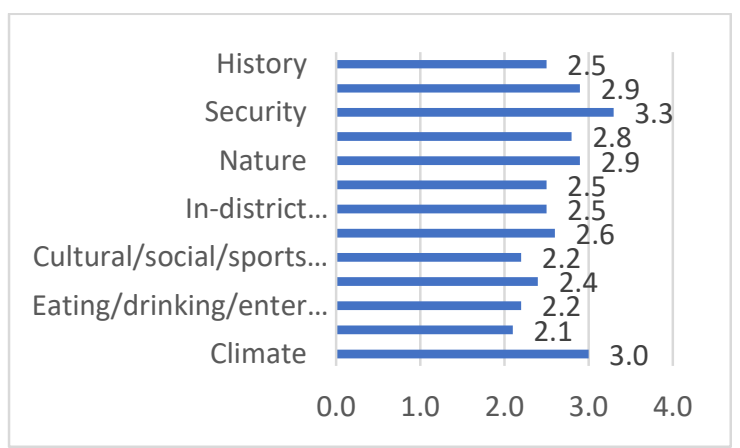

The students' scores show that the most important factors that reduce the concrete image of Köprübaşı are lack of shopping/eating/drinking/entertainment opportunities and cultural/sporting/social events. Their scores also show that they consider the district safe and its climate good, but not much.

The local people's scores show that the most important factors that reduce the concrete image of Köprübaşı are lack of cultural/sporting/social events and shopping/eating/drinking/entertainment opportunities and little urbanization and poor accommodation. Their scores also show that they consider the district safe and its climate good, but not much.

Graph 4. Local People's Perceptions of Concrete Image of Köprübaşı

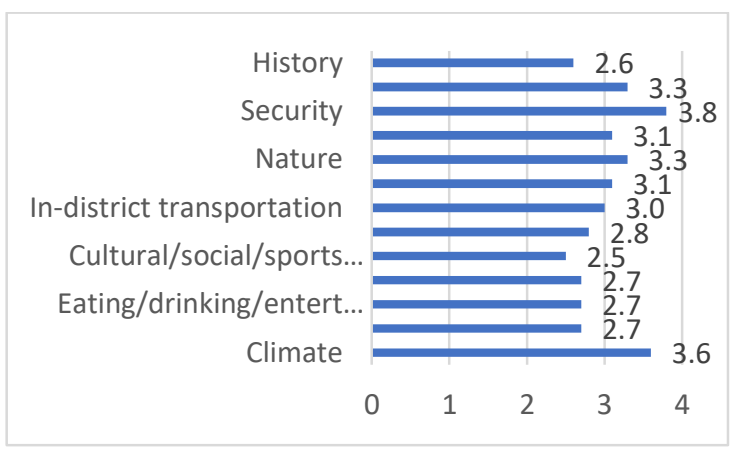

\section{People's Perceptions of Abstract Image of Köprübaşı}

Eight items were used to determine the abstract image of Köprübaşı, and participants were asked to score them on a scale of 1 (most negative) to 5 (most positive). The students find Köprübaşı moderately relaxing, safe and cheap but boring and dull (Graph 5).

Graph 5. Students' Perceptions of Abstract Image of Köprübaşı

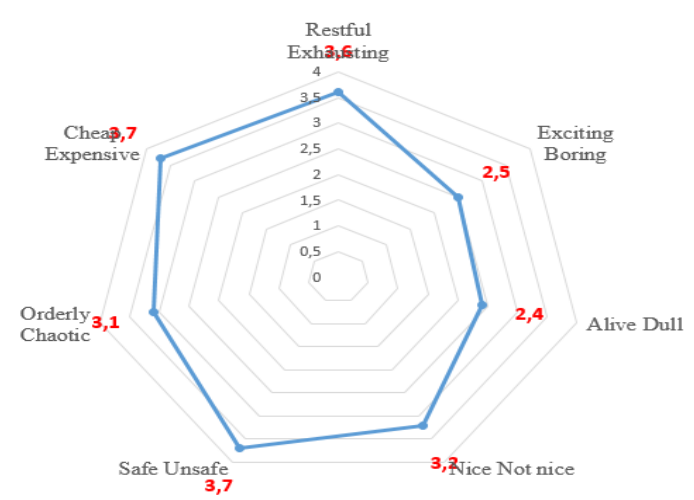

The students' perceptions of the abstract image of Köprübaşı indicate that exciting and inspiring activities should be organized to ignite an interest in the district and that its comfort, safety and cheapness should be highlighted in brand marketing and management.

The local people find Köprübaşı relatively more relaxing, safer and cheaper and yet more boring and dull than the students (Graph 6). 
Graph 6. Local People's Perceptions of Abstract Image of Köprübaşı

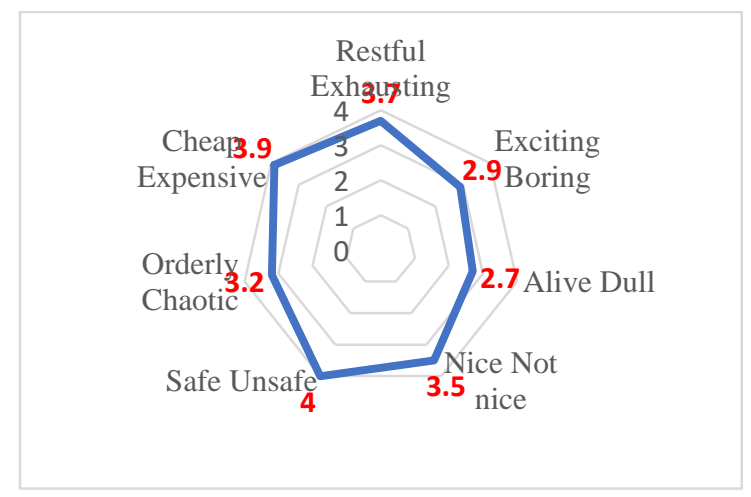

\section{Image of Local People}

The image of a region consists not only of concrete and abstract values but also of local people's characteristics, which are used to define that region, such as "The people of Kayseri are crafty" or "The people of Ankara are aloof." Therefore, what makes a city is the people who actually live there. Their vision, education, ideologies and values are the city itself and therefore, image studies should focus on the characteristics of locals. Twelve items were used to determine participants' perceptions of the local people of Köprübaşı. Graph 7 shows the mean scores of the students.

Graph 7. General Image of Köprübaşı People

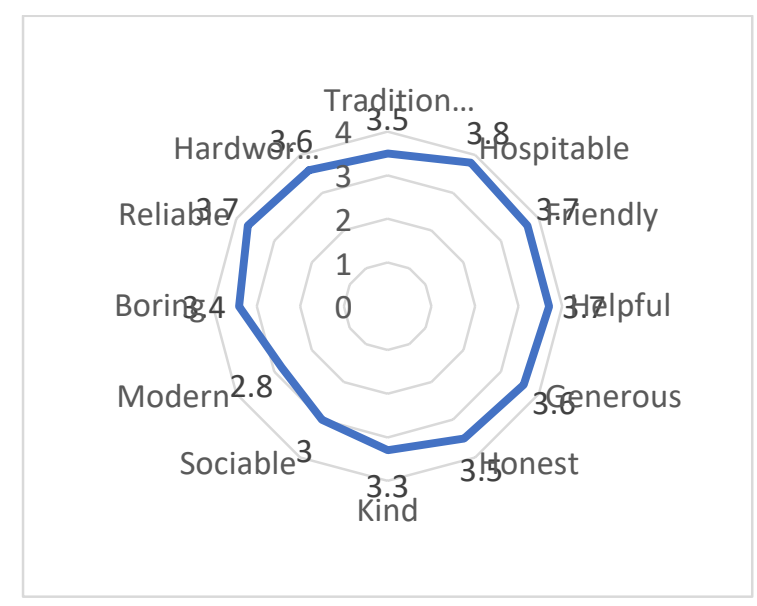

The students have the lowest mean scores on sociable and modern, indicating that they do not consider Köprübaşı people sociable and modern. The other items have a mean score of 3.

The local people also have the lowest mean scores on sociable and modern, indicating that they do not consider themselves sociable and modern. They regard themselves relatively hospitable, friendly, helpful and reliable (Graph 8).
Graph 8. Local People's Perceptions of Themselves

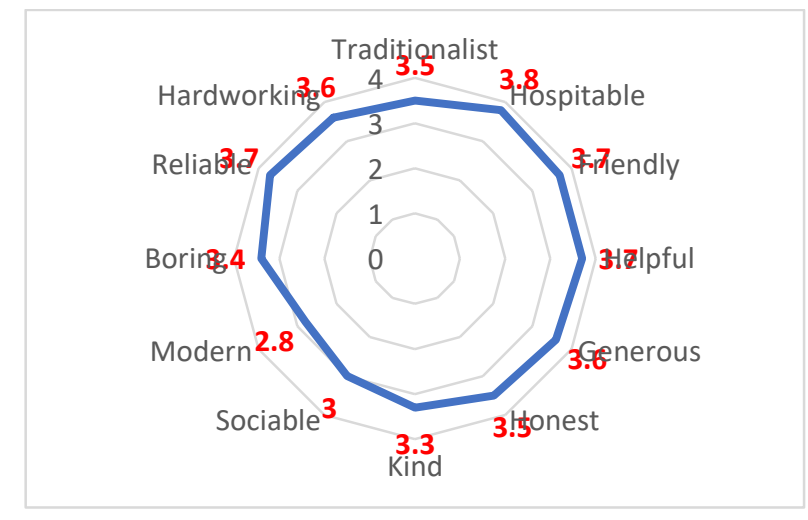

\section{Conclusion and Suggestions}

This study was conducted within the scope of the Manisa Köprübaş1 District Strategic City Marketing Plan Project. It investigated locals' (727) and students' (213) perceptions of Köprübaşı, which is a district of the city of Manisa. Participants find Köprübaşı quiet, peaceful and restful but point out that it should be improved in terms of eating-drinking, entertainment and shopping opportunities and urbanization level. They also state that it has major problems in terms of transportation, health and accommodation.

"Strawberries, tobacco, dam and olives" were the first things that came to participants' minds when they thought of Köprübaşı. Both locals and students agree that agricultural products should be promoted to develop the district. They describe Köprübaşı as an old and calm man and state that blue and turquoise colors symbolize it.

According to participants, Köprübaşı is a safe district with good climate, however, it has very few shopping, entertainment, cultural and social centers and sports facilities (concrete image). Participants find Köprübaşı relaxing, cheap and safe but boring and dull (abstract image).

Several suggestions were made based on the findings.

1. Köprübaşı is quiet and safe, and therefore, it can be awarded the title "Cittaslow."

2. Participants describe Köprübaşı as "an old and calm man." Therefore, the "old man" should be rejuvenated and modernized, which requires planning of activities that will increase the attractiveness of the district.

3. A shopping mall should be built to increase the attractiveness of the district, and this can be implemented in different ways.

4. Since blue and turquoise colors symbolize the district, all promotional materials and symbols for the district image should be in those colors. 

strawberries, tobacco and olives. Therefore, development plans should focus on agricultural products. Cooperating is the most important step for the production and export of strawberries.

6. Agricultural products should be converted to high value added products for the development of the district.

7. Organic farming should be promoted, and a certification system should be designed to support production.

8. Necessary arrangements should be introduced, and actions should be taken to allow local producers to export to European Union countries.

9. Another thing that comes to mind about Köprübaşı is the dam. Therefore, fishing activities should be promoted and the area around the dam should be turned into a center of attraction. Such activities as fishing, camping and canoeing should be held.

This study determined locals' and students' perceptions and expectations of Köprübaşı and provided feedback to the managers of Köprübaşı about their services. It is, therefore, a strategic guide for the Köprübaşı District Governorship, Köprübaşı Municipality and other senior managers of Köprübaşı. In the short run, the results can be used to develop the District Development Plan, to prioritize services and to determine how the district resources should be allocated. In the long run, they can also help administrators to implement the Strategic City Marketing Plan, and thus, turn Köprübaşı a Brand city and provide a high quality of life for all inhabitants.

\section{References}

1. Aaker, D. (1996), "Building Strong Brands", The Free Press, NY.

2. Acar, İ., Erdoğan, S., Gedikli, A., (2015), “Gaziantep Şehir Kimliği Çalıştayı Sonuç Raporu”, Gaziantep Büyükşehir Belediyesi, Nisan.

3. Akgül, A. and Çevik, O., (2005), "İstatistiksel Analiz Teknikleri”, “SPSS'te İşletme Yönetimi Uygulamaları", Emek Ofset Ltd.Şti, İkinci Baskı, Ankara.

4. Asnawi, A. (2016), "City Marketing: Chronological Definitions", Available from: http:/ ssrn. Com /abstract=2832540, [Accessed 23 June, 2019]

5. Ashworth, GJ, (2001), "The Communication Of The Brand Images Of Cities", Paper Presented At The Universidad Internacional Menendez Pelayo
Conference: The Construction And Communication Of The Brand Images Of Cities, Valencia.

6. Ashworth, GJ., and Voogd H, (1990), "Selling The City: Marketing Approaches In Public Sector Urban Planning”, Belhaven Press, London.

7. Aytaç, M. and Öngen, B., (2012), “ Doğrulayıc1 Faktör analizi ile yeni çevresel paradigma ölçeğinin yapı geçerliliğinin incelenmesi”, İstatistikçiler Dergisi, Say1:5, pg.14-21.

8. DAKA- Doğu Anadolu Kalkınma Ajansı, "Muş İli Şehir Pazarlaması ve Markalaşması, Muş İlinde Üretilen Ürünlerin Markalaşması, Değerinin Artırılması ve Pazarlanması", Kertenkele, Temmuz 2014. Available from: www.kertenkele.com.tr, [Accessed 19 May, 2019]

9. Ergen, A. (2015), "Şehir Pazarlaması ve Marka Şehirler Yaratmak", Avaible from: http://www.thebrandage.com/sehir-pazarlamasi-vemarka-sehirler-yaratmak-4230 [Accessed 23 june, 2019]

10. Fırat, Aytekin and Kömürcüoğlu, F., (2015), "Muğla Şehir Markası ve İmaj Algısı; Muğla Sıtkı Koçman Üniversitesi Öğrencileri Üzerine Bir Alan Araştırması", Yönetim Bilimleri Dergisi, Cilt:13, Say1:26, pg.285-304.

11. Gelibolu, L., Kanıbir, H., Saydan H., vd., (2014), "Kars Algısı İmajı ve Marka Kimliği Araştırması", Serhat Kalkınma Ajansı, Ed: Uğur Çalışkan-Hüseyin Tutar-Selen Sallan, Kars.

12. Gilboa, S., Eugene D.J., Vianelli, D., Pastore, P., Herstein, R., (2015), “A Summated Rating Scaler For Measuring City Image", Cities 44, pg.51.

13. Gürbüz, S. and Şahin, F., (2016), "Sosyal Bilimlerde Araştırma Yöntemleri Felsefe-Yöntem-Analiz", Seçkin Yayınevi, Gözden Geçirilmiş 3. Baskı, Nisan 2016, Ankara

14. Hankinson, G. and Cowking P, (1993), "Branding In Action - Cases And Strategies For Profitable Brand Management”, McGraw-Hill Book Company, London. 
15. İZKA- İzmir Kalkınma Ajansı, (2015), “İzmir Kentsel Pazarlama Stratejik Planı", Avaible from: www.izka.org.tr, [Accessed 19 May, 2019]

16. Karavatzis, M. (2004), "From City Marketing to City Branding: Toward a Theoretical Framework For Developing City Brands", Place Branding, Vo:1:1, pg.58-73.

17. Kavaratzis, M. (2008). "From City Marketing to City Branding: An Interdisciplinary Analysis With Reference To Amsterdam, Budapest and Athens.

18. Kestane, S.Ü., Ateş, A.M., Kestane, Ö. (2018), "Doğrulayıcı Faktör Analizi İle Şehir Algı Ölçeğinin Yapı Geçerliliğinin İncelenmesi: Manisa Köprübaşı İlçesi Örneği”, Multidisipline Çalışmalar-4 (Sosyal Bilimler), Cilt 1, Editör: Abidin Temizer ve İbrahim Serbestoğlu, Instıtut za Geografiju, Podgorica, Montenegro.

19. Murph, L., (2016), "Destination Brand Personality Testing the Applicability of Aaker's Brand Personality Dimentions to Tourism Destinations Using Confirmatory Faktor Analysis", Tourism Travel and Research Association: Advancing Tourism Research Globally 17.

20. Noivana, D. and Rufaidah, P. (2012), "Dimentions of City Marketing", The Global Advance Research Conference on Management and Business Studies (GARCOMBS),At Bandung, Indonesia, Nowember.

21. Merriless, B., Miller,D., Herrington, C. (2009), Antecedents of Residents' City Brand Attitudes, Journal of Business Research , 62, pg.362-367.

22. Meyda, C.H. and Şeşen, H., (2015), "Yapısal Eşitlik Modellemesi Amos Uygulamaları”, Detay Yayıncılık, 2. Bask1, Ankara.

23. Özdemir, Ş. and Karaca, Y.,(2009), "Kent Markası ve Marka İmajının Ölçümü: Afyonkarahisar Kenti İmajı Üzerine Bir Araştırma”, Afyon Kocatepe Üniversitesi, İ.İ.B.F. Dergisi, Cilt.X I,Sayı. I,2009, pg.113-134.

24. Rainisto, S.K., (2003), "Success Factors of Place Marketing: A Study of Place Marketing Practices In Northern Europe And The United States", Doctoral
Dissertation, Helsinki University Of Technology, Institute Of Strategy And International Business.

25. Sezgin, M. and Ünüvar, Ş., (2011), "Sürdürülebilirlik ve Şehir Pazarlaması Ekseninde Yavaş Şehir", Çizgi Kitabevi Yayınları, Konya, Aralık.

26. Short, J.R., Breitbach, S., Buckman, S. and Essex, J., (2000), From World Cities to Gateway Cities. City, (4): pg. 317-340.

27. Yilmaz, A.S. and Yücel, N., (2016), "Yerel Kalkınmada Yeni Bir Anlayış: Kentlerin Markalaşması", Çağdaş Yerel Yönetimler, Cilt:25, Say1:1, pg.61-78. 